\title{
Europe appoints science adviser
}

\section{Scottish cell biologist Anne Glover hopes to influence EU policy-making.}

\section{BY NATASHA GILBERT IN BRUSSELS}

$\mathrm{T}$ he dearth of independent, sound scientific advice in European policymaking provokes endless complaints from science advocates, who blame it for the continent's wrangling over charged issues such as genetically modified crops and nanotechnology.

They might finally have a saviour, in the person of Anne Glover, a Scottish molecular and cell biologist, who was named last week as Europe's first chief scientific adviser.

More than two years after pledging to create the post, José Manuel Barroso, the president of the European Commission, officially announced Glover's appointment on 5 December. He also outlined her role, ending long-standing speculation about the extent of the job's remit. Nature first reported that Glover had won the job on 21 November (see Nature http://doi.org/g8k; 2011).

"I have long pressed for the creation of a high-level scientific adviser at the heart of the European Commission, which is key to ensuring that development and implementation of EU policy and legislation are underpinned by a robust evidence base," says John Beddington, the United Kingdom's chief scientific adviser.

Glover, who was not available for interview, spent most of her academic career at the University of Aberdeen, UK, studying microbial

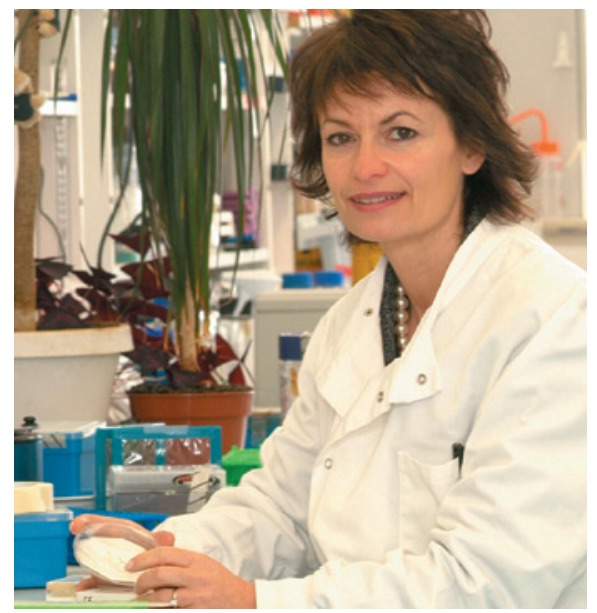

Anne Glover, Europe's first chief scientific adviser.

diversity and how organisms respond to stress at a cellular level. She has served as chief scientific adviser to Scotland's government since 2006, and will leave the job on 21 December before beginning her new life in Brussels in the new year.

Glover will report directly to Barroso, providing him with advice on policy proposals, and guidance on interpreting uncertainty in scientific evidence. She will also have a key role in strategic planning for emergencies - such as the Escherichia coli outbreak that swept across Europe this year - and providing updates on scientific advances and novel technologies. Another key role will be to communicate science to the public, particularly the benefits and risks of new technologies.

Glover will have an office in the Berlaymont building in Brussels, where Barroso works, putting her at the heart of European policy-making. Her position will be at a high managerial level in the European Commission, equivalent to a director-general, which other science advisers believe will give her the independence and authority to succeed.

The Bureau of European Policy Advisers will provide Glover with administrative support. But it is still uncertain whether she will have her own team of scientists to support her. Nor is it clear what her relationship will be with other existing Brussels-based commission advisory groups, such as the European Research Area Board - which advises on research policy - and the Joint Research Centre, a collection of seven research institutes carrying out research relevant to policy.

Ultimately, Glover's success will depend on having "direct access to the relevant science policy-makers", says Robert May, a former chief scientific adviser to the UK government. "She must have the authority to speak the truth, never twisting the science to suit political expedience, but also recognize that policy needs will sometimes override what you think as a scientist." -

\section{Rhapsody for Hungarian science}

\section{Major reforms and extra funding will help free country's researchers from communist legacy.}

\section{BY QUIRIN SCHIERMEIER}

W ith a shake-up of its national academy and a major boost in research funding next year, Hungary hopes to regain its long-lost status as a scientific powerhouse in central Europe.

The Hungarian Academy of Sciences dominates the country's research scene. Like most of its counterparts in the formerly communist countries in central and eastern Europe, it is a cross between a distinguished learned society and an operational research organization, supporting research at universities and employing around 2,800 scientists at 40 research units.
The country has an eminent scientific past, boasting a string of Hungarian-born Nobel prizewinners in the twentieth century. But today its funding and scientific output lag behind those of many other European nations.

"Many of our present institutes have a mundane office air about them when they should be inspiring academic hubs," says József Pálinkás, the academy's president, who has campaigned vigorously for the changes since his re-election in May. "Without more pronounced teamwork and competition we will lose our foothold in the world's scientific community."

At a special general assembly held last week in Budapest, three-quarters of members with voting rights approved a plan to reorganize the academy into ten large multidisciplinary research centres. These will have revised research agendas, modernized management structures and international advisory boards that regularly review operations. Five remaining institutes, including the prestigious Institute of Experimental Medicine in Budapest, will remain separate and keep their existing remits.

Scientists formerly working in isolated institutes will be brought together to pursue more collaborative research at the new centres, which will cover disciplines including photonics and particle physics, astronomy and the Earth sciences, chemistry and materials research, 